\title{
Correction: Metagenomics in ophthalmology: current findings and future prospectives
}

Borroni D, Romano V, Kaye SB, et al. Metagenomics in ophthalmology: current findings and future prospectives. BMJ Open Ophth 2019;4:e000248. doi: 10.1136/ bmjophth-2018-000248.

The license type for this paper has changed from CC BY-NC to CC BY.

Open access This is an open access article distributed in accordance with the Creative Commons Attribution 4.0 Unported (CC BY 4.0) license, which permits others to copy, redistribute, remix, transform and build upon this work for any purpose, provided the original work is properly cited, a link to the licence is given, and indication of whether changes were made. See: https://creativecommons.org/licenses/by/4.0/.

(C) Author(s) (or their employer(s)) 2019. Re-use permitted under CC BY. Published by BMJ.

bmjophth 2019;4:e000248corr1. doi:10.1136/bmjophth-2018-000248corr1

(D) Check for updates 